\title{
AKTUALISASI PENDIDIKAN KARAKTER MELALUI MODEL SERVIS LEARNING DALAM PEMBELAJARAN BAHASA INDONESIA DI SD PARULIAN 5 MEDAN
}

\author{
Vina Merina Br Sianipar \\ Surel:vinamerina05@gmail.com
}

\begin{abstract}
ABSTRAK
Tujuan dari penelitian yaitu 1) untuk mengetahui kemampuan guru dalam mengaktualisasikan model Servis Learning dalam pembelajaran Bahasa Indonesia melalui pendidikan karakter. 2) untuk mengetahui model Servis Learning dalam pembelajaran Bahasa Indonesia. Hal ini dilatar belakangin perkembangan teknologi yang menimbulkan rendahnya karakter generasi muda khususnya siswa SD dari nilai moral dan nilai sosial. Servis Learning merupakan proses pembelajaran yang mengkolaborasi antara tindakan positif dan bermakna di masyarakat dengan pembelajaran akademik, perkembangan pribadi, dan tanggungjawab sebagai masyarakat. Melalui model Servis Learning, guru dapat memberikan ruang bagi siswa untuk peka terhadap lingkungan untuk bisa membedayakan lingkungan, pengalaman, keterampilan dan nilai-nilai yang dituangkan dalam bentuk karangan berupa tulisan dan lisan. Penelitian ini dilakukan dengan menggunakan analisis kualitatif malalui pengumpulan data yaitu angket.
\end{abstract}

Kata Kunci : Pendidikan Karakter, Model Servis Learning, Pembelajaran Bahasa Indonesia

\section{PENDAHULUAN}

Sejak memasuki era reformasi belasan tahun yang lalu telah terjadi perubahan yang cukup signifikan dalam kehidupan bangsa Indonesia, terutama sekali perubahan dalam kehidupan sosial dan politik. Dalam suasana yang seperti itu mulai muncul persoalan baru. Kebebasan yang digulirkan pemerintah oleh sebagian warga masyarakat dijadikan kesempatan untuk bertindak seenaknya sendiri mengabaikan norma-norma yang berlaku, serta tidak mempertimbangkan lagi apakah tindakan yang dilakukan itu merugikan kepentingan orang lain atau tidak. Akibat dari semua itu kehidupan masyarakat diwarnai oleh munculnya pelanggaran normanorma dalam wujud tindak kekerasan seperti tawuran antar kampung, perang antar suku, demonstrasi dengan pengrusakan, tindakan main hakim sendiri terhadap sesama warga,konflik masyarakat dengan aparat keamanan,dan masih banyak yang lainnya.

Berkaitan dengan proses pembelajaran seorang guru dapat mengetahui karakter atau kepribadian peserta didiknya melalui bahasa yang digunakan pada saat berkomunikasi baik di dalam maupun di luar proses pembelajaran. Seseorang guru dapat mengetahui kejujuran, daya intelektual, kesopanan dan karakter dari peserta didiknya dapat diketahui dari tutur bahasa, ekspresi, kalimat yang efektif,

Pascasarjana Universitas Negeri Medan 
dan cara penyampaian yang digunakan pada saat berkomunikasi, baik dengan gurunya, dan sesama temannya. Bahasa yang dimaksudkan dalam berkomunikasi yaitu lisan maupun tulisan. Pendidikan karakter dengan proses pembelajaran bahasa Indonesia memiliki hubungan satu dengan yang lain. Pendidikan karakter terkandung dalam proses pembelajaran bahasa Indonesia. Dalam pembelajaran bahasa Indonesia terdapat nilai-nilai yang terkandung dalam pendidikan karakter di antaranya kejujuran, intelektualitas, sopan santun, dan rasional .

Pendidikan berbasis karakter merupakan salah satu upaya dalam pembaharuan di dunia pendidikan, besar pengaruhnya penanaman karakter pada anak dianggap sebagai hal pokok. Hal ini mengisyaratkan bahwa mutu pendidikan peserta didik sangat penting untuk ditingkatkan. Karakter merupakan nilai-nilai perilaku manusia yang berhubungan dengan Tuhan Yang Maha Esa, diri sendiri, sesama manusia, lingkungan, dan kebangsaan yang terwujud dalam pikiran, sikap, perasaan, perkataan, dan perbuatan berdasarkan norma-norma agama, hukum, tata krama, budaya, dan adat istiadat.

Pendidikan tidak cukup hanya menjadikan seseorang menjadi pintar dan menguasai ilmu dan teknologi, akan tetapi juga menjadikan peserta didik memiliki kepribadian yang baik. Dengan kata lain bahwa pendidikan mengarah pada dua aspek yaitu, It,s matter of having dan It,s matter of being. Aspek yang pertama berkenaan dengan pengetahuan dan pengalaman akademis, ketrampilan profesional, ketajaman dan kedalaman intelektual, serta kepatuhan pada nilai-nilai atau kaidah keilmuan. Sedangkan aspek yang kedua berkenaan dengan pembentukan kepribadian peserta didik. (Siswomihardjo,2001).

No. 20 Tahun 2003 Tentang Sistem pendidikan nasional pada pasal 3, yang menyebutkan

bahwa Pendidikan Nasional berfungsi mengembangkan kemampuan dan membentuk karakter serta peradaban bangsa yang bermartabat dalam rangka mencerdaskan kehidupan bangsa. Pendidikan nasional bertujuan untuk berkembangnya potensi peserta didik agar menjadi manusia yang beriman dan bertakwa kepada Tuhan Yang Maha Esa, berakhlak mulia, sehat, berilmu, cakap, kreatif, mandiri, dan menjadi warga negara yang demokratis serta bertanggung jawab sedangkan salah satu untuk mendapatkan pendidikan dengan nilai-nilai mulia, berakhlak, kreatif, dan memiliki karakter sesuai budaya bangsa dapat diperoleh melalui penggunaan bahasa yang baik. Seperti yang ditekankan pada pernyataan di atas, bahasa ternyata memiliki peranan dalam pengelolaan dan menciptakan generasi penerus yang memiliki nilai lebih. Dengan alasan itulah, perlunya menganalisa lebih jauh bagaimana pendidikan karakter dalam pembelajaran bahasa.

Servis learning (SL) yaitu model pembelajaran yang memfasilitasi siswa untuk memberdayakan pengetahuan, keterampilan, pengalaman, dan nilai-nilai. Servis learning merupakan proses pembelajaran yang mengkolaborasi antara 
tindakan positif dan bermakna di masyarakat dengan pembelajaran akademik, perkembangan pribadi dan tanggungjawab (Maurice, 2010: 115).

Servis learning menjadi pilihan yang tepat karena di dalamnya terdapat unsur yang bersifat melayani dan menolong orang melalui pemahaman dan pengamantan siswa dari hasil karyanya atau karya siswa lainnya dalam bentuk tulisan.melalui model Servis learning maka pendidikan karakter yang telah menurun akibat perkembangan zaman dan teknologi akan meningkat kearah positif. Hal ini juga harus menjadi pusat perhatian guru bukan hanya dalam pembelajaran tetapi memperhatikan lingkungan tempat siswa bermain seperti diluar sekolah.

Kegiatan dalam Servis learning membantu siswa ikut berperan dalam kegiatan masyarakat. Kegiatan ini dapat ditungkan siswa dalam bentuk tulisan berupa karangan baik cerpen maupun puisi. Hal ini juga akan terlihat dari segi sikap dan perbuatan siswa dalam melaksanakan tugas. Guru akan melatih siswa untuk memecahkan masalah dari hasil pengamatan sekitar yang ditungkan ke dalam tulisan sehingga siswa lain yang mendengar atau membaca hasil temannya mengetahui makna dari pesan tersiratnya.

Penelitian ini dilakukan sebagai langkah mengindentifikasi bagaimana aktualisasi pendidikan karakter melalui model Servis learning pada pembelajaran Bahasa Indonesia di SD Parulian 5 Medan.

\section{METODE PENELITIAN}

Untuk mengkaji aktualisasi pendidikan karakter dilakukan penelitian terhadap guru SD di Parulian 5 Medan. Pengambilan sample dilakukan secara cluster sampling. Metode pengumpulan data berupa angket . Objek penelitian adalah aktualisasi pendidikan karakter melalui model Servis Learning.

\section{HASIL PENELITIAN DAN PEMBAHASAN}

Berdasarkan hasil penelitian dari hasil angket yang telah dilakukan terhadap sample penelitian, diperoleh informasi sebagaimana dipaparkan berikut ini.

Berdasarkan hasil penelitian diperoleh informasi bahwa tingkat aktualisasi guru dalam pendidikan karakter di SD sebesar 87,95 \%, berarti termasuk pada kategori sangat tinggi. Hal ini diperoleh dari observasi lapangan.

Berdasarkan angket terbuka yang diisi oleh responden dapat diketahui bahwa para guru dalam mengaktualisasikan pendidikan karakter melalui model Servis learning proses pendidikan di sekolah. Hal ini dalam proses pembelajaran, dilakukan melalui berbagai cara, baik melalui contoh nasehat maupun tugas:

Sikap kritis

Aktualisasi sikap kritis dilakukan guru terhadap siswa dengan cara memberikan kesempatan untuk: mengajukan pertanyaan, penguatan dan tugas, 
diskusi, menerima kritik, ketika berpen- dapat didukung referensi, memberi umpan balik, mau menerima pendapat berbeda, berpikir logis dan divergen.

Sikap jujur

Aktualisasi sikap jujur yang dilakukan guru terhadap siswa adalah menjadi contoh, bukan memberi contoh, mengatakan sesuatu yang didengar, dilihat dan dirasakan sebagai sebuah kenyataan, terbuka, objektif, memberitahu dengan jelas kepada siswa yang tidak jujur, guru menunjukkan aturan main, tidak semena-mena terhadap segala bentuk kekurangan siswa, mengingatkan siswa untuk tidak berbuat tidak terpuji, jawaban siswa harus jujur, menyamakan antara pikiran, ucapan dan perbuatan, minta maaf bila salah, atau tidak bisa menjawab, sesuai dengan hati nurani, tidak berpura-pura.

Sikap tanggung jawab

Aktualisasi sikap tanggungjawab yang dilakukan guru terhadap siswa berupa: minta laporan tugas, masuk tepat waktu, peduli lingkungan, memberikan umpan balik, menjadi pertimbangan dalam memberikan penilaian, melakukan koreksi tugas siswa, menyediakan buku paket dan pendukung, melaksanakan tugas dengan sebaik-baiknya, memberikan motivasi, menanamkan etika, menyadari kesalahan, memberikan latihan atau tugas-tugas sebagai pembiasaan.

\section{Sikap Disiplin}

Aktualisasi sikap disiplin guru terhadap siswa berupa: siswa tepat waktu dalam berbagai hal (tugas, hadir), mengabsen siswa, mengawali dan mengakhiri dengan berdoa, keluar kelas harus ijin petugas, guru hadir tepat waktu, mengikuti aturan permainan, pemberian sangsi, siswa yang salah ditegur, tugas yang sudah dikoreksi dikembalikan siswa, memenuhi janji, disiplin menjadi pertimbangan dalam memberikan penilaian.

\section{Sikap kasih sayang}

Aktualisasi sikap kasih sayang guru terhadap siswa berupa: Sabar, memberi semangat, memberi hiburan, komunikasi yang harmonis, empaty, pemahaman latar belakang sosio- psikologis siswa, mengingatkan dengan bahasa yang santun, jika ditanya tidak dapat menjawab tidak malu, siswa boleh menyampaikan keluh kesahnya, memberikan nasihat, dan pujian, memberi contoh perilaku yang baik, membantu menyelesaikan masalah, menganggap siswa sebagai teman, tidak pilih kasih, tidak membedakan, tidak rendah diri., siswa dianggap anaknya sendiri, membuat kondisi nyaman

Sikap ikhlas

Aktualisasi sikap ikhlas guru terhadap siswa berupa: tidak mengeluh, menerima siswa sebagaimana adanya, bekerja hanya mengharap ridho Yang Maha Kuasa, tanpa pamrih, kerja sebaik-baiknya, cerah, semangat tidak kelihatan lelah, memberikan layanan yang baik, menerima persoalan siswa, 
kerja tanpa beban, dan kerja sebagai ibadah.

Berdasarkan hasil penelitian sebagaimana dilakukan di atas jelaslah bahwa aktualisasi nilai-nilai dasar pendidikan karakter guru SD sangat bagus. Begitu pula cara-cara mengaktualisasikan juga sangat rinci, serta mereka memberikan alasan yang esensial dan instrumental terkait dengan pertanyaan mengapa nilai-nilai tersebut ditanamkan kepada siswanya melalui model Servis Learning dalam sistem pembelajaran. Pada sisi lain,instrumen penelitian ini ditujukan kepada guru, sehingga kemungkinan diperoleh informasi yang lebih nyata. Artinya, penelitian lanjutan dapat dilakukan dengan responden siswa. Siswa diharapkan dapat diperoleh informasi yang relatif obyektif. Guru akan mengarahkan siswa melalui model Servis Learning untuk membentuk karakter siswa yang tidak baik menjadi baik. Siswa akan melihat atau mengamati kejadian di lingkungannya dan akan ditulis dalam bentuk karangan seperti cerpen dan puisi. Lebih lanjut, siswa akan membacakan karya dan siswa lain mendengar untuk mendapatkan pesan atau amanat dari karya siswa tersebut. Hal ini akan membantu tingkat pemahaman siswa dibantu dengan penjelasan guru dalam kelas. Siswa yang kurang mengerti akan bertanya ataupun sebaliknya guru akan memberikan umpan pertanyaan untuk melihat tingkat pengetahuan siswa akan pembelajaran.

Berdasarkan data diperoleh informasi bahwa para guru mengaktualisasikan nilai-nilai dasar yang terkandung dalam pendidikan karakter melalui model Servis Learning karena alasan sebagai berikut :

a. Sikap kritis

Guru mengaktualisasikan sikap kritis sebagai nilai dalam pendidikan karakter melalui proses pendidikan dengan alasan sikap ini dapat: mengembangkan ilmu dan wawasan, kreativitas dan pola berpikir, sikap percaya diri, sikap demokratis, serta meningkatkan kinerja guru. .

b. Sikap jujur

Guru mengaktualisasikan sikap jujur sebagai nilai pendidikan karakter melalui proses pendidikan di sekolah dengan alasan sikap ini: menumbuhkan kesadaran manusia, membentuk kepribadian, menjadi kunci keberhasilan, menjadi modal dasar membangun karakter, merasa tenang dan damai, tidak takut., tercipta keadilan dan kesejahteraan

c. Sikap tanggungjawab

Guru mengaktualisasikan sikap tanggungjawab sebagai nilai pendidikan karakter melalui proses pendidikan di sekolah dengan alasan sikap ini: diperlukan dalam kehidupan.. merupakan ibadah, modal sukses, kreativitas berkembang, menjadikan seseorang mandiri, mencetak generasi yang tangguh 


\section{d. Sikap disiplin}

Guru mengaktualisasikan sikap disiplin sebagai nilai pendidikan karakter melalui proses pendidikan di sekolah dengan alasan sikap ini: menjadi modal dasar keberhasilan, meningkatkan kualitas akademik, memberikan contoh lebih baik daripada ucapan, disiplin merupakan sumber segalanya, dapat membentuk karakter.

e. Kasih sayang

Guru mengaktualisasikan sikap kasih sayang sebagai nilai pendidikan karakter melalui proses pendidikan di sekolah dengan alasan sikap ini: menjauhkan diri dari sikap semena- mena, mempererat hubungan antar manusia, membuat nyaman, agar tidak rendah diri, agar tumbuh rasa kemanusiaan, merupakan unsur utama dalam memberikan layanan, agar siswa senang, tidak takut, saling memahami, mudah menerima informasi, optimal.

f. Ikhlas

Guru mengaktualisasikan sikap ikhlas sebagai nilai pendidikan karakter melalui proses pendidikan di sekolah dengan alasan sikap ini merupakan ibadah, bekerja tanpa beban, siswa bekerja dengan baik, nyaman, ringan, dengan sikap ikhlas akan memperoleh makna, ikhlas merupakan sifat dasar dalam mendidik.

Berdasarkan data tersebut, penanaman nilai-nilai dasar yang terkandung dalam pendidikan karakter dilakukan oleh guru tersebut sangat bermanfaat dalam kehidupan manusia, baik untuk pengembangan diri, sosial dan religius. Artinya, para guru meyakini pentingnya nilai-nilai dasar pendidikan karakter tersebut untuk ditanamkan kepada para siswa.

\section{SIMPULAN}

Aktualisasi pendidikan karakter yang berupa sikap kritis, kejujuran, tanggungjawab, disiplin, kasih sayang dan ikhlas yang dilakukan oleh guru SD pada kategori sangat baik. Aktualisasi pendidikan karakter dalam proses pendidikan dilakukan melalui model Servis learning mengahasilkan keteladanan atau meneladani, memberi contoh, menegur, memberitahu, memberi sangsi, dan memberi tugas. Model Servis Learning, guru dapat memberikan ruang bagi siswa untuk peka terhadap lingkungan untuk bisa membedayakan lingkungan, pengalaman, keterampilan dan nilai-nilai yang dituangkan Nilai-nilai yang terkandung pada pendidikan karakter perlu dilakukan pembiasaan oleh guru karena pendidikan karakter tersebut sangat esensial dan diperlukan dalam kehidupan manusia, baik untuk pengembangan diri, sosial dan religius.

Berdasarkan hasil angket diajukan rekomendasi: Tindakan meneladani guru merupakan kunci utama pendidikan karakter, karenanya dalam proses pendidikan, 
lembaga penghasil tenaga kependidikan khiususnya guru harus memberikan teladan bagi siswa SD dan perlu penelitian lanjutan terkait dengan aktualisasi pendidikan karakter dengan menggunakan model Servis learning pada pembelajaran Bahasa Indonesia baik guru dan peserta didik .

\section{DAFTAR RUJUKAN}

Aris Setiawan. 2010 Gamelan Mendunia karena Humanis. Kompas, Minggu 10 Oktober 2010. Jakob.

Arthur A, Carin and Robert B, Sund. 1985. Teaching Modern . United States of America: Charles E. Merrill Publishing Co.

Maurice. 2010. Servis Learning Handbook. North Carolina: Guilford County Schools. Diakses di www.gcsnc.com?ing/pdf/ServisLearningHandbook.pdf pada tanggal 30 September 2016).

Maxwell, John. 2013. How Successful People Lead. New York: Hatchette Book Group.

Sumarjo. 2011. Kriminal atau Pahlawan. Kompas, Sabtu 22 Januari 2011.

Sudiyono, dkk. 2009. Peningkatan soft skill melalui focus group discussion berbasis lapangan pada perkuliahan manajemen pendidikan. Penelitian dibiayai oleh Program HIbah Kompetisi Institusi.

Sarlito, Wirawan. 2011. Majalah Seputar Indonesia, tanggal 6Maret 2011.

Seto Mulyadi. 2011. Jangan Bohing lagi sayang, Kompas, Sabtu, 22 Januari 2011.

Suyanto dan Djihad Hisyam. 2000. Pendidikan di Indonesia Memasuki Milenium III. Yogyakarta: AdiCita.

Wahyu Widhiarso. 2009. Evaluasi Soft Skill dalam Pembelajaran, Makalah disampaikan pada Kegiatan Seminar dan Sarasehan "Evaluasi Pembelajaran Mata Kuliah Dasar Kependidikan” di FIPP UNY tanggal 14 Pebruari 2009.

Wildasky, Aaron. 1997. Self Evaluation Organization. California: University of California at Barkley.

Zuchdi, Darmiyati. 2009. Pendidikan Karakter, Grand Design dan nilai-nilai target, Yogyakarta: UNY Press . 
